\title{
マイクロ波放電式イオンエンジンの高比推力化に関する基礎研究*1 Fundamental Research of High Specific Impulse Microwave Discharge Ion Engine
}

\author{
林寛 ${ }^{* 2}$-碓井 美由紀 ${ }^{* 3} \cdot$ 中 山宜 典 ${ }^{* 4} \cdot$ 清 水幸 $*^{* 2}$ \\ Hiroshi Hayashi, Miyuki Usui, Yoshinori Nakayama, Yukio Shimizu, \\ 西山和 孝*2.國 中 均 ${ }^{* 2}$ \\ Kazutaka NishiYAma and Hitoshi KuninaKA
}

\begin{abstract}
Key Words : Ion Engine, High Specific Impulse, Microwave Discharge, Numerical Simulation, Grid Optics, High Voltage Insulation
\end{abstract}

\begin{abstract}
An ion engine with 10,000 sec-class high specific impulse is expected as primary propulsion for interplanetary space mission with extremely high delta- $\mathrm{V}$, and needs high voltage for ion acceleration over $10 \mathrm{kV}$. The microwave discharge ion source without solid electrodes can supply sophisticated technologies and simple composition on electrical isolation for such a high voltage. New electro-static grid made of carbon-carbon composite material was fabricated based on the numerical simulation of "igx" code. The " $\mu 10 \mathrm{HIsp"} \mathrm{ion} \mathrm{engine} \mathrm{combining} \mathrm{the} \mathrm{ECR} \mathrm{ion} \mathrm{source,} \mathrm{microwave}$ discharge neutralizer, DC blocks, propellant isolators, carbon-carbon composite grid and so on generated successfully a plasma beam with $10,000 \mathrm{sec}$ specific impulse using $15 \mathrm{kV}$ acceleration voltage.
\end{abstract}

記 号の説明

$C_{\mathrm{i}}:$ イオン生成コスト $[\mathrm{W} / \mathrm{A}]$

$D:$ グリッド孔径 $[\mathrm{mm}]$

$e:$ 素電荷量 $\left(=1.602 \times 10^{-19} \mathrm{C}\right)$

$g:$ 重力加速度 $\left(=9.8 \mathrm{~m} / \mathrm{sec}^{2}\right)$

Isp : 比推力 $[\mathrm{sec}]$

$J:$ 電流 $[\mathrm{mA}]$

$l:$ グリッド間隔 $[\mathrm{mm}]$

$m:$ 質量 $[\mathrm{kg}]$

$n:$ グリッド孔総数 [個]

$N P / H:$ 規格化パービアンス $\left[\mathrm{A} / \mathrm{V}^{3 / 2}\right]$

$P_{\mathrm{h}}:$ パービアンス $\left[\mathrm{A} / \mathrm{V}^{3 / 2}\right]$

$t:$ グリッド厚さ $[\mathrm{mm}]$

$V:$ グリッド電圧 $[\mathrm{V}$ or $\mathrm{kV}]$

$v:$ 速度 $[\mathrm{m} / \mathrm{sec}]$

$\eta_{\mathrm{t}}:$ 推進効率

$\eta_{\mathrm{u}}:$ 推進剂利用効率

添 字

$\mathrm{a}:$ アクセルグリッド

$\mathrm{b}:$ :ヒーム

*1 C) 2007 日本航空宇宙学会

平成 18 年 6 月 7 日, The 25 th International Symposium on Space Technology and Science において一部発表. 平成 19 年 6 月 8 日原稿受理

*2 宇宙航空研究開発機構宇宙科学研究本部

*3 東京大学大学院工学系研究科航空宇宙工学専攻

$* 4$ 防衛大学校システム工学群航空宇宙工学科 $\mathrm{d}:$ 放電，イオン生成

$\mathrm{e}:$ 実効

$\mathrm{g}:$ グリッド間

i : イオン

limit : 逆流リミット

$\mathrm{s} ：$ スクリーングリッド

$500 \mathrm{~V}$ : アクセル電圧 $500 \mathrm{~V}$ における

1. は じめに

マイクロ波放電式イオンエンジン (第 1 图) は, マイク ロ波放電によりイオン化した推進剂を高電圧か印加された 加速グリッドを用いて, 静電的に噴射して推力を発生する 電気推進機である ${ }^{1)} . \mathrm{ECR}$ プラズマ生成によって，優れた 耐久性や運用性を実現するマイクロ波放電式イオンエンジ ンのアイディアガ提案されたのは 1980 年代後半のことであ る. 兴の後, 文部科学省宇宙科学研究所 (現 ISAS/JAXA) がイオン源の高性能化, 中和器のマイクロ波放電化 ${ }^{2)}$, カー ボン/カーボン $(\mathrm{C} / \mathrm{C})$ 複合材製グリッド $\left.{ }^{3}\right)$ の採用などの革 新的な改良を图り, 飛躍的に关の推進性能と耐久性を向上 させた .さらに 2003 年に打ち上げられた工学試験探査機 「はやジさ」には, $10 \mathrm{~cm}$ 級マイクロ波放電式イオンエンジ ン $\mu 10$ (推力 $8 \mathrm{mN}$, 比推力 3,200 秒) が世界で初めて搭 載された .これらのイオンエンジンは 26,000 時間・台の累 積作動時間と $1.4 \mathrm{~km} / \mathrm{sec} の \Delta V$ を達成し，わが国初のイ オンエンジンによる惑星間航行技術を確立した4).

「はやぶささやNASA の Deep Space 15) のようにイオ ンエンジンは近年, 惑星探査機の主推進システムとして活 


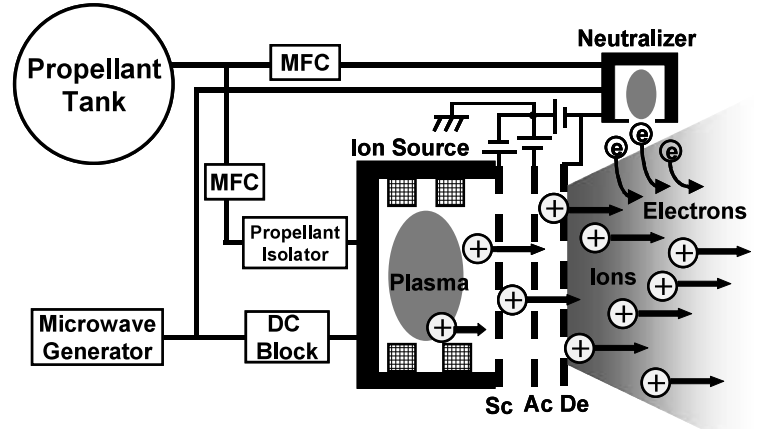

第1図 マイクロ波放電式イオンエンジン

躍している .しかしながら , 現在のところ探査機での発生 電力か数 $\mathrm{kW}$ 程度に制約されているため, これに搭載され るイオンエンジンの比推カレベルは 3,000 秒程度が主流と なっている.今後の惑星探査ミッションの展開として , 宇宙 原子炉や大面積太陽電池により数十 $\mathrm{kW}$ オーダーの電力が 供給できるようになれば，比推力が 5,000 秒以上の高比推 カイオンエンジンで木星などの外惑星の探査ミッションが 実現されることが予想される. 害際にNASA が高比推力イ オンエンジンによって木星の衛星を目指す JIMO (Jupiter Icy Moon Orbiter) 計画 ${ }^{6}$, ISAS/JAXA がンーラーセイ ルと高比推カイオンエンジンを併用したハイブリッドセイ ルによって木星を目指すソーラー電力セイル実証探査機7) を弚れ光れ提案している。

面積か数百〜数千 $\mathrm{m}^{2}$ の薄膜太陽電池を展開することに より，地球近傍 (1 天文単位) において数十 $\mathrm{kW}$ オーダーの 電力を発生できるので, 米国などのように宇宙原子炉に頼 らずに木星探査が可能になる . 太陽から遠くなるに伴い発 生電力は急激に減少するが，イオンエンジンは供給電力が 比較的豊富な地球近傍から火星あたりまでの領域で駆動さ せるため, 光の運用に何ら支障はない . 前述のソーラー電力 セイル実証探査機では, ソーラーセイルの一部表面に実装 された薄膜太陽電池 (面積約 $200 \mathrm{~m}^{2}$ ) により 1 天文単位で $10 \mathrm{~kW}$ 以上の電力を発生して , これで高比推力イオンエン ジンシステムを駆動させることになっている .このような背 景から比推力が 5,000 秒を超える高比推カイオンエンジン の実現か期待されている.アメリカではNASA/Glenn Research Center (GRC) が中心となって , 高比推カイオンエ ンジンの研究開発を進めており ${ }^{8)}$, 現在は消費電力 $14 \mathrm{~kW}$, 比推力 4,670 秒の NEXT (NASA's Evolutionary Xenon Thruster) ${ }^{9)}$ や消費電力 $25 \mathrm{~kW}$, 比推力 6,000 秒の HiPEP (High Power Electric Propulsion) の研究開発に取り組ん でいる10).

さて，イオンエンジンの比推力は次式で記述される .

$$
I s p=\frac{\eta_{\mathrm{u}}}{g} v_{\mathrm{i}}=\frac{\eta_{\mathrm{u}}}{g} \sqrt{\frac{2 e V_{\mathrm{b}}}{m_{\mathrm{i}}}}
$$

(1) 式に示されるようにイオンエンジンを高比推力化する には加速グリッドの加速電圧を増大させるか, 質量か軽い 推進剂ガスを用いればよい . 比推力が 3,000 秒程度のイオ
ンエンジンは, $1 \mathrm{kV}$ 程度の加速電圧でイオンを $30 \mathrm{~km} / \mathrm{sec}$ 程度の排出速度て噴射している.これに対して高比推力イ オンエンジンでは，排出速度は約 $50 \mathrm{~km} / \mathrm{sec}$ 以上に及っジ 加速電圧は $3 \mathrm{kV}$ 以上になる . また , 推進剂として従来 のキセノンより質量が軽いクリプトンやアルゴンが有力な 候補となる . NASA/GRCでは, 推進剤としてクリプトン を使用して加速電圧 $13 \mathrm{kV}$ で比推力 14,000 秒を達成した 例がある ${ }^{11)}$.

これまで研究されてきた高比推力イオンエンジンの多く は直流放電式イオンエンジンであるが, 本研究ではマイク 口波放電式イオンエンジンの高比推力化を対象とする . 光 の理由として , 以下に示す 2 つが挙げられる .

(1) 加速電圧を大きくする場合, 直流放電式ではプラズマ 生成用電源か加速用電源より高電位にバイアスされるた め, 複雑な絶縁処置が必要となる.一方, マイクロ波放 電式の場合では基準電位にあるマイクロ波電源から DC ブロックを介して給電するので簡素な構成となる .

(2) イオンエンジンの推進効率は次式となる ${ }^{12)}$.

$$
\eta_{\mathrm{t}}=\frac{\eta_{\mathrm{u}}}{1+\left(C_{\mathrm{i}} / V_{\mathrm{b}}\right)}
$$

ここで通常 $C_{\mathrm{i}}$ は直流放電式およびマイクロ波放電式で

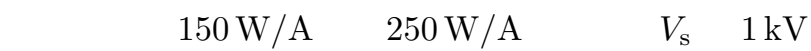
程度である 3,000 秒級イオンエンジンでは $C_{\mathrm{i}}$ は，推進効 率を左右する重要な要素となる . 一方 , 比推力が 10,000 秒級のイオンエンジンでは $V_{\mathrm{s}}$ が $10 \mathrm{kV}$ 以上となるので, $C_{\mathrm{i}}$ の依存性は小さくなる .

従って，マイクロ波放電式イオンエンジンは，推進性能 と耐久性に優れた高比推力推進システムとなる可能性を秘 めており，最近では HiPEP でもマイクロ波放電式を採用 する方向にある ${ }^{13)}$.

イオンエンジンの高比推力化に際しては，いくつかの技 術的課題がある. 弚の第一はグリッドオプティクス設計で ある . 高比推力加速グリッドは, 後述のように従来の加速 グリッドとは異なった設計が必要である.第二に加速グリッ ド間の絶縁，DC ブロック (マイクロ波伝送系) やガスア イソレータ (推進剤ガス系) の絶縁耐圧を向上させなけれ ばならない.さらに宇宙機への搭載に際しての技術的課題 を列挙すると推力電力比の低下, 高電圧電源に関する諸課 題（絶縁処置/昇圧手段/重量増大/排熱など）などが挙げ られる. 推力電力比の低下については， $\mu 10$ の半分以下に 低下するので著しい消費電力の増大を招くが, 前述のよう にソーラー電力セイル実証探査機では比較的潤沢な電力供 給が見込めるので問題はない，高電圧電源については，国 内の探査機で $10 \mathrm{kV}$ 以上の電圧を出力する高電圧電源が搭 載された例があり，これを通じて絶縁処置や昇圧手段に関 する技術やノウハウは十分に得られている . 但し ，イオン エンジン用電源は電流容量が比較的大きくなる分, 弚の開 発はやや困難になり，特に排熱設計が厳しくなる．乥こで 電源設置面の放熱面積をできる限り広く設計し，ヒートポ ンプにより排熱能力を向上させるなどの工夫が必要になる． 高電圧電源の重量は発生電圧より電力に依存し, 出力電力 
が約 $2.5 \mathrm{~kW}$ になる高比推カイオンエンジン用電源では , 同 規模の宇宙用電源の重量を踏まえると $10 \mathrm{~kg}$ 程度になると 推測される.これは $\mu 10$ 用電源の 1.4 倍に相当する重量で あり，すでに同等の重量の電源が搭載された実績がある .

ISAS/JAXA では 2003 年度より, $\mu 10$ の比推力を 10,000 秒に向上させた高比推力マイクロ波放電式イオンエンジン $\mu 10 \mathrm{HIsp}$ の開発を進めている. 本研究は产の基礎研究とし て，イオンエンジンの高比推力化に関わる技術課題の中で 特に重要な高比推力用加速グリッドと各種絶縁機器に関す る技術の確立をねらいとするものである . 本研究の目的は 次に示す 3 つである.

(1) 加速電圧 $15 \mathrm{kV}$ での安定したイオン加速を達成し， $\mu 10 \mathrm{HIsp}$ の推進性能を評価する .

(2) 加速グリッドのイオンオプティクス特性, 電子逆流特 性およびビームプロファイルを取得し，これを筆者の一 人である中山が開発した三次元イオンビーム解析コード “igx”による解析結果と比較する .

（3）DC ブロックなどの絶縁機器の絶縁性能，健全性を実 証およひ評価する。

本稿では, 高比推力マイクロ波放電式イオンエンジンの基 盤技術である高比推力加速グリッドと各種絶縁機器の試作 と光れらを用いたイオン加速試験の結果について報告する。

\section{2. 高比推カマイクロ波放電式} イオンエンジン $\mu 10 \mathrm{HIsp}$

$\mu 10 \mathrm{HIsp}$ は 2010 年代以降に想定される木星探査などの 惑星探査ミッションに対応するため, ISAS/JAXA が研究 開発を進めている高比推力マイクロ波放電式イオンエンジ ンである . 弚の開発にあたっては $\mu 10$ 用イオン源と中和器 を谷のまま活用し，加速グリッドと各種絶縁機器を新規開 発して高比推力化を図ることを基本方針とする . 第 1 表に $\mu 10 \mathrm{HIsp}$ と $\mu 10$ の主要諸元を示す . $\mu 10 \mathrm{HIsp}$ はソーラー電 カセイル実証探査機への搭載を想定して比推力 10,000 秒， 推力 $27 \mathrm{mN}$ の推進性能を目標としている. 宇宙機への搭載 を想定したイオンエンジンで比推力が 10,000 秒を超えるも のか開発された例はなく， $\mu 10 \mathrm{HIsp}$ は世界的にも最高水準 の性能を目指している．また，イオン生成コストや推進剤 利用効率も $\mu 10$ と同レベルを目指す . 推進剤タンク重量の 増大を避けるため, 推進剂ガスの変更は行わずキセノンを 使用し, 加速電圧の増大のみで高比推力化する . 兴の加速 電圧は $\mu 10$ の 10 倍となる $15 \mathrm{kV}$ であり， $140 \mathrm{~mA}$ のビー 么電流を引き出す . 総消費電力は $2.5 \mathrm{~kW}$ であり，推力電力

第 1 表 $\mu 10 H I s p$ の主要諸元

\begin{tabular}{lrc}
\hline \multicolumn{1}{c}{ 項 目 } & $\mu 10 \mathrm{HIsp}$ & $\mu 10$ (参考) \\
\hline 加速電圧 $[\mathrm{kV}]$ & 15 & 1.5 \\
マイクロ波電力 $[\mathrm{W}]$ & 36 & 36 \\
総推進剂流量 $[\mathrm{sccm}]$ & 2.85 & 2.85 \\
ビーム電流 $[\mathrm{mA}]$ & 140 & 140 \\
推力 $[\mathrm{mN}]$ & 27 & 8 \\
比推力 $[\mathrm{sec}]$ & 10,000 & 3,180 \\
推進剂利用効率 & 0.85 & 0.85 \\
イオン生成コスト $[\mathrm{W} / \mathrm{A}]$ & 230 & 230 \\
\hline
\end{tabular}

比は $\mu 10$ の半分以下の $11 \mathrm{mN} / \mathrm{kW}$ となる . 耐久性につい ては, ソーラー電力セイル実証探査機におけるイオンエン ジンの要求作動時間が約 9,500 15,000 時間と想定されて (いるため $)^{7)}, \mu 10$ と同等の 20,000 時間以上を目標とする .

ソーラー電力セイル実証探査機へは 4 台 (1 台は冗長系) の $\mu 10 \mathrm{HIsp}$ が搭載される見込みであり, システムの総重量 は約 $90 \mathrm{~kg}$ （推進剂重量を除く）となる.このうち高電圧 電源とマイクロ波電源の総重量は $50 \mathrm{~kg}$ であり, システム 全体の半分以上を占める . システム全体の最大消費電力は およ光 $8 \mathrm{~kW}$ であり，最大で 3 台のエンジンを同時運転さ せることにより $80 \mathrm{mN}$ の推力を発生する . 推進阂のキセノ ンは重量が約 $10 \mathrm{~kg}$ の球型タンクに約 $65 \mathrm{~kg}$ 充填され，調 圧制御部とガス分配部を介してエンジンにブローダウンさ れる.

\section{3. 高比推力化に向けたコンポーネント 試作}

3.1 高比推力加速グリッド 高比推カイオンエンジンの 加速グリッドは，消費電力を削減するために従来の弚れよ り低パービアンスで設計する .さらにグリッド間での放電 を防止するためにグリッド間隔を広くする．これに伴って アスペクト比 (スクリーン孔径と実効加速長の比) 整合の ため，グリッド孔の直径も大きくなる．加えて，隣接する ビームレット同士の静電的干渉の抑制，イオン放出面（イ オンシース) の維持，電子逆流の防止のため，各グリッド が厚いことも特徵である.

本研究でも $\mu 10 \mathrm{HIsp}$ 用に上記のような高比推力仕樣の加 速グリッドを新規に設計・試作した ${ }^{14)}$.グリッド設計に際し て，何通りもの設計パラメータを組み合わせたグリッドを 用いて，実験的にグリッド設計の最適化を図ることは膨大 な費用と時間を要する．乥こで効率良くグリッド設計を進 めるため，加速グリッドの初期設計の支援に三次元イオン ビーム解析コード “igx”による数值計算を活用した . "igx" コードは三次元イオンビーム解析の効率化及び低計算コス 卜化を図るため，荷電粒子の放出面設定や移動記述などの 新規化，または改良された解析計算手法が導入された計算 解析コードである.すでに他の計算解析コードや小型イオ ンエンジンによる実験結果との比較から，短時間で妥当な 解が求められることか確認されている15,16).

$\mu 10 \mathrm{HIsp}$ 用加速グリッドは 3 枚式であるが，本解析では 計算の簡易化のために 2 枚式グリッドでグリッドオプティ クスの解析計算を行った . まず, グリッド間の放電を防止 するために少なくとも 4〜 $5 \mathrm{~mm}$ のスクリーンーアクセル間 距離が必要であるが，ここではマージンをとり $5.5 \mathrm{~mm}$ と した .また，アスペクト比を $\mu 10$ とほぼ同等（約 1.3）と するため，スクリーン孔径は $7 \mathrm{~mm}$ とした . $\mu 10 \mathrm{HIsp}$ では イオン源内部の圧力を $\mu 10$ と同等とするため, スクリーン 及びアクセルグリッドの開口率を $\mu 10$ と同じく $67 \%$ (スク リーン)，24\% (アクセル) とした .

計算条件は推進剂利用効率 0.8 , スクリーン及びアクセ

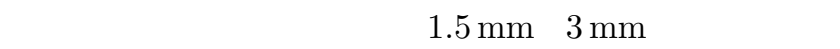
圧を $-500 \mathrm{~V}$ として推進剤ガスをキセノン，イオン源内部 


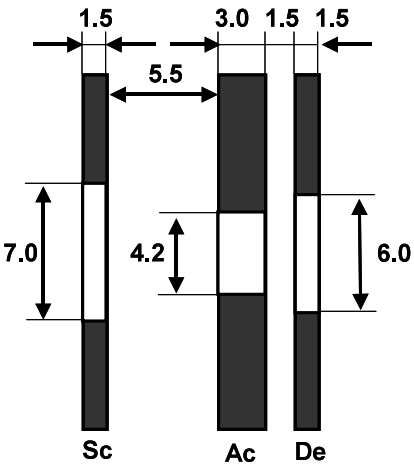

第 2 図 加速グリッドの配置

のプラズマの電子温度を $3 \mathrm{eV}$, エンジン周囲の背圧を $0 \mathrm{~Pa}$ に設定した . 以上の条件で生成プラズマの不均一性を考慮 して 0.6 2.0 mA のビームレット電流の範囲で, スクリー ン電圧が $8 \sim 17 \mathrm{kV}$ の範囲で $1 \mathrm{kV}$ 刻み, アクセル孔径は $2.4 \sim 5.0 \mathrm{~mm}$ の範囲から $0.6 \mathrm{~mm}$ 刻みでそれれぞれ変えてい き，これらを組み合わせた計 480 ケースのグリッド設計を 解析した . 各ケースの計算結果に対して, (1)イオン軌道が アクセルグリッドに直撃しないこと，(2)電荷交換衝突（以 下，CEX）によるイオン電流の割合が $0.1 \%$ 以下であるこ と，(3)エンジン下流からの電子逆流が生じないこと，また は軽微なアクセルグリッドの設計変更で対処できることの 基準を満たすことを評価して,グリッド設計の最適化を行っ た . 計算・解析は Pentium4-2.4 GHz 搭載のパーソナルコ ンピュータを使用し，1 ケースの計算・解析に要する時間 は 2 分弱である .

加速グリッドのイオン抽出性能はパービアンスで評価す るが，イオンエンジンでは 1 つのグリッド孔に着目した規 格化パービアンスで評価する . 解析により加速電圧が 10〜 $15 \mathrm{kV}$ の範囲では最適な規格化パービアンスは $0.5 \sim 1.1 \times$ $10^{-9} \mathrm{~A} / \mathrm{V}^{3 / 2}$ であり，これに相当するビームレット電流の 範囲は $0.8 \sim 1.2 \mathrm{~mA}$ であることが分かった . また , ビーム レット電流が小さくなるほど最適解が多くなる傾向が見ら れ，特にビームレット電流が $0.8 \mathrm{~mA}$ 付近が最適であると 示された.一方, アクセル孔径については $4.2 \mathrm{~mm}$ で, ス クリーン電圧が $10 〜 17 \mathrm{kV}$ の幅広い範囲で最適となること が判明した .

以上の結果を踏まえてビームレット電流を $0.86 \mathrm{~mA}$ に設 定し, グリッド孔の総数は 163 個とした . アクセル孔径は上 記の解析結果から $4.2 \mathrm{~mm}$ とした . 兴の他のグリッド厚さや 距離などは解析に用いた值を採用し，これに厚さ $1.5 \mathrm{~mm}$ ， 孔径 $6 \mathrm{~mm}$ (開口率 $42 \%$ ) のディセルグリッドをアクセル グリッドの下流 $1.5 \mathrm{~mm}$ の位置に配置する.グリッドの材質 は $\mu 10$ での採用実績を有する $\mathrm{C} / \mathrm{C}$ 複合材を採用する . 第 2 図に $\mu 10 \mathrm{HIsp}$ 用加速グリッド配置を示す.また，第 3 図 に “igx”コードによる最終的なグリッド設計での抽出イオ ン軌道のシミュレーション結果を示すが, 抽出されたイオ ンが適度に収束され，アクセルグリッドに衝突することな く適切な軌道を描いていることが分かる。

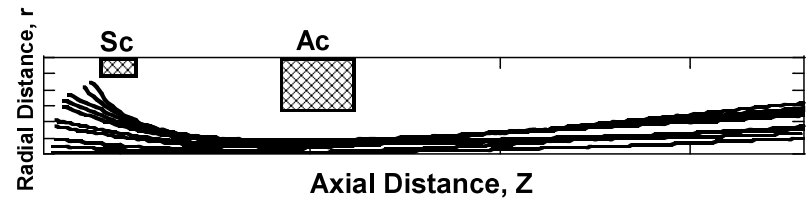

第3図“igx”コードによるイオン軌道の計算結果

3.2 絶縁機器の試作 キセノンを推進剂として比推力 10,000 秒を達成する場合，マイクロ波放電式では $\mu 10$ でさ え推進剂利用効率は 0.85 であるため, $15 \mathrm{kV}$ 程度の加速電 圧が必要となり直流放電式より要求耐電圧が厳しい，本研 究では $\mu 10 \mathrm{HIsp}$ に向けて $30 \mathrm{kV}$ 耐圧を目標として，高耐 圧仕樣の DC ブロックとガスアイソレータを試作した . 高 耐圧 DC ブロックとして室化ホウ素 (BN) を絶縁材とする 高耐圧/低損失の導波管型 DC ブロックを試作した。絶縁 材としては絶緑特性とマイクロ波特性に優れたPTFE も候 補に挙がつたが，沿面放電や宇宙放射線に対する耐性が劣 るため BN を採用した。しかし，BNで目標の耐圧性能を 達成するには $3 \mathrm{~mm}$ 以上の厚さが必要であり，ママイクロ波 電力の損失か懸念される. 艺こで本 DC ブロックでは絶縁 材のマイクロ波透過部分に半波長板を採り入れ, 導波管フ ランジにはチョークフランジを採用してマイクロ波電力の 低損失化を图っている.試作された DC ブロックは単体で の評価試験により耐電圧 $30 \mathrm{kV}$ 以上 , マイクロ波電力の挿 入損失 $5 \%$ 以下 (@ $4.2 \mathrm{GHz}$ ) の性能を有することを確認し た ${ }^{17)}$. 一方，高耐圧ガスアイソレータとしては $\mu 10$ 用の光 れと同じくドーナツ型碍子を介して金属メッシュを等間隔 に配列するシールドメタル方式のガスアイソレータを採用 した . ガスアイソレータの方式としては粉末充填方式など も考えられるが, 本研究では $\mu 10$ での実績を考慮してシー ルドメタル方式とした ${ }^{18)}$. 高耐圧化を図るため $\mu 10$ 用ガ スアイソレータから変更点として, ケース材質をガラスエ ポキシからセラミックに変更すると共に光の形状も見直し た .さらにシールドメッシュを支持するスペーサのサイズ や形状の大幅な变更も高耐圧化に寄与している.試作され たガスアイソレータは, 真空中での評価試験でキセノン流 量 $2.3 \mathrm{scmm}$ で $25 \mathrm{kV}$ 以上の耐電圧を達成し, 目標性能に は届いていないか実験室レベルでは十分な性能を実現した 。

\section{4. 実 験 方 法}

本研究では，第 1 章に示した目的のために $\mu 10 \mathrm{HIsp}$ の試 作モデルを試作して，兴のイオン加速試験を実施した .

本試作モデルは第 1 図に示したようにイオン源, 中和器 , マイクロ波供給系, 推進剂ガス供給系, 加速電源系から構成 されている.イオン源及び中和器の運転条件は, マイクロ波 電力 $(4.2 \mathrm{GHz})$ が光れ光れ $36 \mathrm{~W}$ (イオン源) , $10 \mathrm{~W}$ (中和 器), キセノン流量は $2.35 \mathrm{sccm}$ (イオン源), $0.5 \mathrm{sccm}$ (中 和器) である . 加速時のグリッド電圧は $15 \mathrm{kV}$ (スクリー ン),$-500 \mathrm{~V}$ (アクセル) であり，ディセルグリッドは中 和面をできるだけ上流側に引き寄せて , イオンビームの発 散を抑制するために中和器と同電位 $(-30 \mathrm{~V}$ 程度) にバイ 
アスした .イオン源とマイクロ波電源及び推進剂ガス供給 系は, 弚れ光れ高耐圧 DC ブロック及びガスアイソレータ により絶縁した .

$\mu 10 H I s p$ のイオン加速試験は直径 $2 \mathrm{~m}$, 長さ $5 \mathrm{~m}$, 最高 到達真空度が $1.3 \times 10^{-4} \mathrm{~Pa}$ (ガス導入無し) の大型真空 槽19)において実施した .

推進性能の評価は $\mu 10 \mathrm{HI}$ sp の加速電圧一イオン電流特性 を計測し, 加速電圧が $15 \mathrm{kV}$ でのビーム電流から推力, 比 推力, 推進剂利用効率，イオン生成コストを算出した .

イオンオプティクス特性は, 規格化パービアンスとアク セル電流導入率 (ビーム電流に対するアクセル電流の比率) の特性により評価した . 実験ではアクセル電圧を $-500 \mathrm{~V}$ 一定としてスクリーン電圧を $2 \sim 15 \mathrm{kV}$ でのビーム電流を計 測し，これから規格化パービアンスを求めた．本研究では， 加速グリッドの規格化パービアンスは次式で規格化した .

$$
\begin{aligned}
& N P / H=\frac{P_{\mathrm{h}}}{\left(D_{\mathrm{s}} / l_{\mathrm{e}}\right)^{2}} \\
& P_{\mathrm{h}}=\frac{J_{\mathrm{b}} / n}{V_{\mathrm{s}}^{3 / 2}}
\end{aligned}
$$

なお，(3-a) 式中の実効加速長は次のように求めた .

$$
l_{\mathrm{e}}=\sqrt{\left(l_{\mathrm{g}}+t_{\mathrm{s}}\right)^{2}+D_{\mathrm{s}}^{2} / 4}
$$

規格化パービアンスの值が最適であれば，CEXによるイ オンのみがアクセルグリッドに流入するので, アクセル電 流導入率が最も低くなる．最適值より低い場合はイオン軌 道が大きく湾曲され交差する (Cross-over) ので, 弚の值 が低くなるほどアクセル電流導入率が増大する . 一方, 最 適値より高い場合はイオン軌道が発散するので, 关の值が 大きくなるほどアクセル電流導入率か増大していく . 規格 化パービアンスが最適領域と Cross-over 領域との境界值 を Cross-over limit といい, 同じく発散領域との境界値を Perveance limit と呼ぶ. 本実験では規格化パービアンス とアクセル電流導入率特性から， $\mu 10 \mathrm{HIsp}$ 用加速グリッド の最適な規格化パービアンス領域および Cross-over limit ， Perveance limit を求めると共にこれを“igx”コードによ る計算結果と比較した .

電子逆流特性試験は, 最初にスクリーン電圧を一定とし てアクセル電圧を $-500 \mathrm{~V}$ から $50 \mathrm{~V}$ ずつ上げて, 各アク セル電圧值におけるスクリーンとアクセル電流を計測した . 次に兴の計測値をWilbur ら ${ }^{20)}$ の手法を参考にして , 次式 によって規格化ビーム電流増加率を求めた .これは各アク

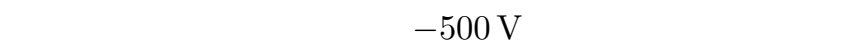
どのくらいビーム電流か増加しているかを示しており, 単 位は\%である .

$$
J_{\mathrm{b}} / J_{500 \mathrm{~V}}=\frac{\left(J_{\mathrm{s}}-J_{\mathrm{a}}\right)-\left(J_{\mathrm{s}}-J_{\mathrm{a}}\right)_{500 \mathrm{~V}}}{\left(J_{\mathrm{s}}-J_{\mathrm{a}}\right)_{500 \mathrm{~V}}} \times 100
$$

本実験では, スクリーン電圧が $2 \sim 15 \mathrm{kV}$ の範囲で $1 \mathrm{kV}$ 刻みでアクセル電圧に対する規格化ビーム電流増加率の特 性をプロットし，弚の值が $0 \%$ の領域と増加する領域に乥れ
ぞれ接線を引き, 并の両者の交点を逆流リミット值とした .

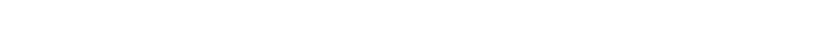
共に, 逆流リミット值からスクリーン電圧と逆流リミット 値との特性についても評価した .

ビームプロファイルは, エンジン下流 $20 \mathrm{~mm}$ の位置に ファラデープローブを設置し，これをエンジン中心から半径 方向に約 $1 \mathrm{~mm}$ 刻みで走査して計測した .計測は直径 $1 \mathrm{~mm}$ のタングステン棒を外径 $2 \mathrm{~mm}$, 内径 $1 \mathrm{~mm}$ のセラミック ス管で被覆した平板プローブを使用した . なお，計測中は プローブへの電子の入射を防ぐために $-60 \mathrm{~V}$ の電圧をバイ アスした . 計測されたプローブ電流から各計測箇所でのイ オン電流密度を算出してビームプロファイルを評価した .

\section{5. 実 験 結 果}

$\mu 10 \mathrm{HIsp}$ のイオン加速試験において , 最初の課題は円滑

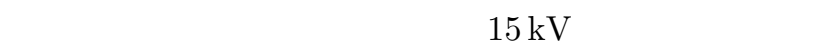
達成することである．まずプラズマ点火を試みて，円滑に プラズマ点火できることを確認した . その後, 徐々に加速 電圧を印加してイオン加速を行った . 兴の結果，イオン加 速直後はグリッド間で軽微な放電が発生したが, 次第に沈 静化され加速電圧 $15 \mathrm{kV}$ でのイオン加速を達成した . 第 4 図 (a)，(b) にイオン加速中の $\mu 10 \mathrm{HIsp}$ の樣子を，第 5 図 に光の加速電圧-イオン電流特性を弚れ光れ示す. $\mu 10 \mathrm{HI}$ sp は非常に安定したイオン加速ができており, 新規に試作さ れた DC ブロックやガスアイソレータも健全に機能し , 光 の設計の妥当性か確認された . 第 4 図 (b)では, 加速グリッ ド直近で各グリッド孔から放出されるビームレットが 1 本 ずつ明確に観察され非常に興味深い. 加速電圧-イオン電流

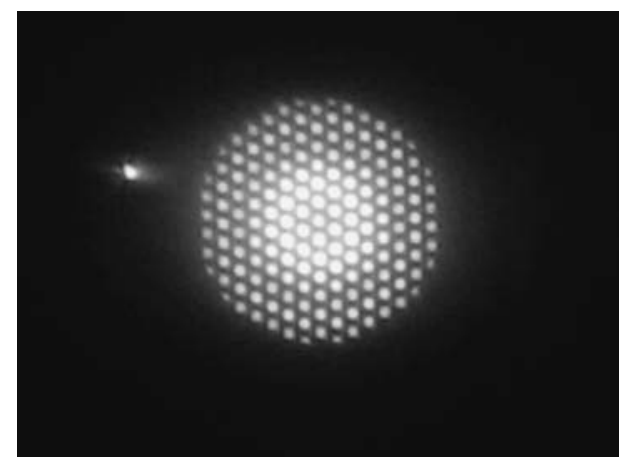

(a) 正面

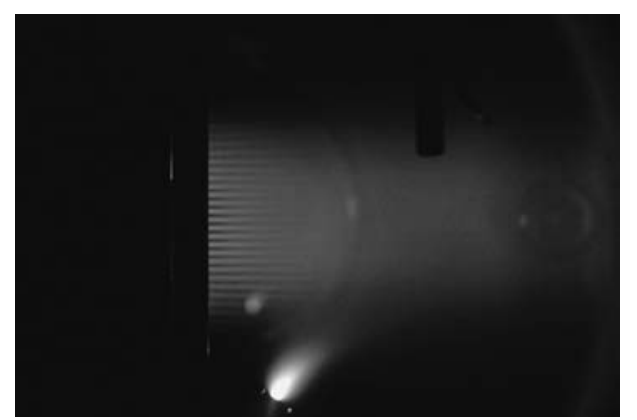

(b) 真横

第 4 図 イオン加速中の $\mu 10 \mathrm{HIsp}$ 


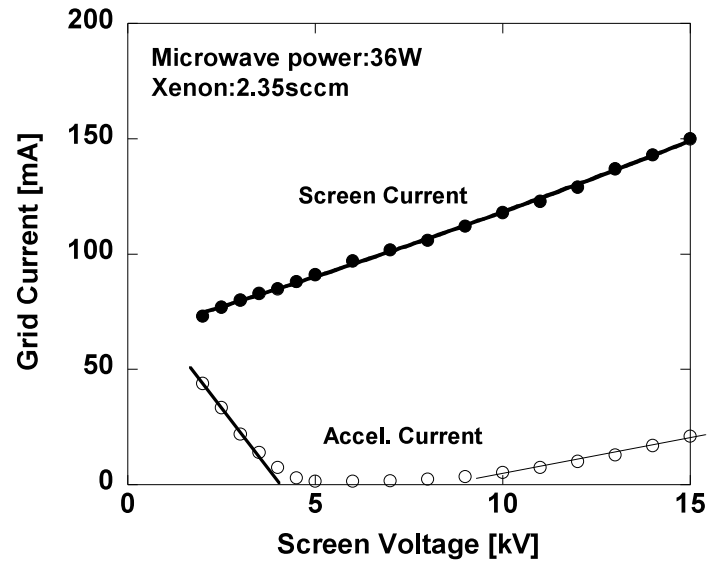

第 5 図 $\mu 10 \mathrm{HIsp}$ の加速電圧一イオン電流特性

\begin{tabular}{lrr}
\multicolumn{4}{c}{ 第 2 表 $\mu 10$ HIsp の推進性能 } \\
\hline \multicolumn{1}{c}{ 項 目 } & 達成値 & 目標値 \\
\hline 加速電圧 $[\mathrm{kV}]$ & 15 & 15 \\
マイクロ波電力 $[\mathrm{W}]$ & 36 & 36 \\
総推進剂流量 $[\mathrm{sccm}]$ & 2.85 & 2.85 \\
ビーム電流 $[\mathrm{mA}]$ & 130 & 140 \\
推力 $[\mathrm{mN}]$ & 26 & 27 \\
比推力 $[\mathrm{sec}]$ & 9,570 & 10,000 \\
推進剂利用効率 & 0.77 & 0.85 \\
イオン生成コスト $[\mathrm{W} / \mathrm{A}]$ & 278 & 230 \\
\hline
\end{tabular}

特性に示されるように, 加速電圧 $15 \mathrm{kV} て ゙ 150 \mathrm{~mA}$ のスク リーン電流が得られた . ほぼ所定のスクリーン電流が抽出 できていることから $\mu 10 \mathrm{HIsp}$ でも $\mu 10$ とほぼ同樣のプラズ マ生成が実現できていると推測できる．しかし，スクリー ン電圧が $8 \mathrm{kV}$ を超えたあたりからアクセル電流が次第に増 加し, 加速電圧 $15 \mathrm{kV}$ では $20 \mathrm{~mA}$ のアクセル電流が流れて いる. 従って，最終的に得られたビーム電流は $130 \mathrm{~mA}$ と なる.これを踏まえて算出した $\mu 10 \mathrm{HIsp}$ の推進性能を第 2 表に示す .なお，推力及び比推力の算出に際してはイオン ビームの発散，二価イオンの影響は考慮していない .ここに 示したように推力 $26 \mathrm{mN}$, 比推力 9,570 秒を達成した .こ れは $\mu 10$ のおよ光 3 倍の推進性能に相当する.また , $\mu 10$ とほぼ同等の運転状況が実現できていることからイオン生 成コストは $\mu 10$ と同等の值が羍成されていると思われるが， ビーム電流が目標よりやや低いので計算上は目標值より大 きくなっている . 推進剤利用効率も抽出イオンの一部をア クセルグリッドで損失しているので，低くなっている．

第 6 図に規格化パービアンスとアクセル電流導入率の特 性を示す.ここに示されるように $1.5 \times 10^{-9} \mathrm{~A} / \mathrm{V}^{3 / 2}$ 前後 に最適なパービアンス領域が存在し, Cross-over limit と

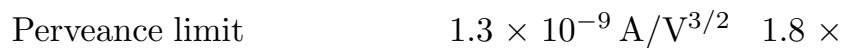
$10^{-9} \mathrm{~A} / \mathrm{V}^{3 / 2}$ であった .これは加速電圧が $5 \sim 7 \mathrm{kV}$ で最適 なイオン軌道となり，15kVでは Cross-over 状態となって いることを示している．さらに第 6 図では，"igx”コード による計算結果も載せたが，両者を比較すると最適な規格 化パービアンスの領域はほぼ一致しているが，実験結果の 方が最適領域の幅か狭くなっている .

スクリーン電圧が $5,10,15 \mathrm{kV}$ での電子逆流特性を

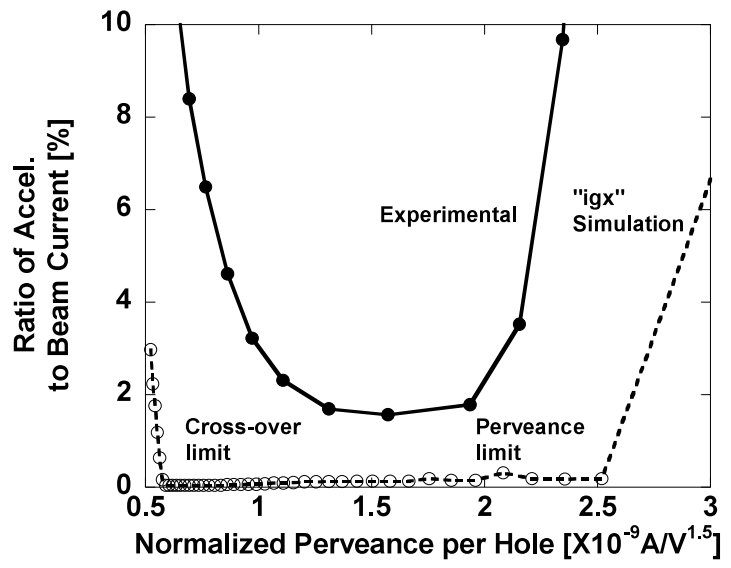

第 6 図＼cjkstart規格化パービアンス-アクセル電流導入率特性

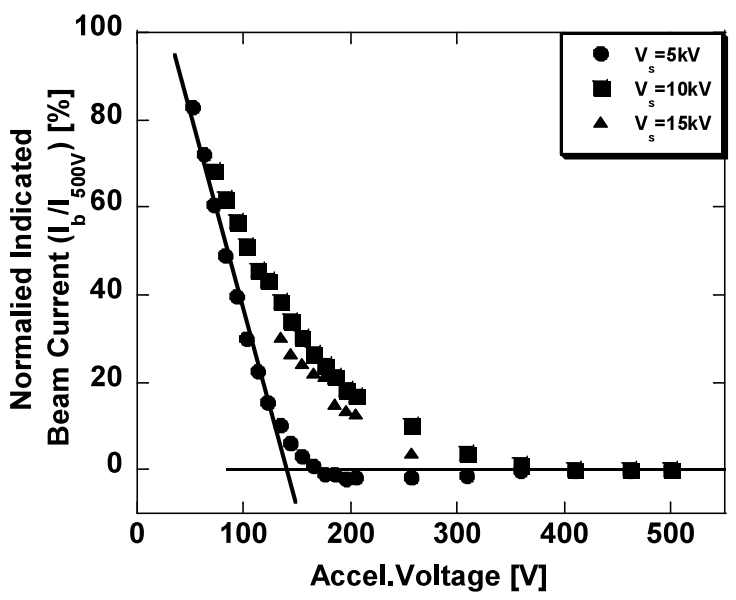

第 7 図 $\mu 10 \mathrm{HIsp}$ の電子逆流特性

第 7 図に示す .なお, アクセル電圧は負電圧であるが, 第 7 图では絶対値で表示されていることに留意されたい，いず れもアクセル電圧が逆流リミット值を下回ると電子逆流が 生じて急激にビーム電流が増大している . 2 本の接線の交 点から求めた逆流リミット值はスクリーン電圧が $5 \mathrm{kV}$ では 約 $140 \mathrm{~V}$ である. 同じ手法でスクリーン電圧が $10,15 \mathrm{kV}$

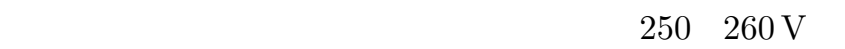
なった . 但し，第 7 図にも示されるようにスクリーン電圧 が高くなるほど，電子逆流特性の膝部分が滑らかになるた め, 接線の交点から逆流リミット值を求めることが困難に なる. 弚のためにスクリーン電圧が高い領域では, 実際の 逆流リミット值は接線の交点が求められる值よりも高いと 思われる.第 8 図では各スクリーン電圧に対する逆流リミッ 卜値をプロットしたが，スクリーン電圧が高くなると逆流 リミット值も高くなっている.一方，Kaufmanによれば， 逆流リミット值は次のような半経験式で示される ${ }^{21)}$.

$$
\left|V_{\text {limit }}\right|=\frac{0.2 V_{\mathrm{b}}}{\frac{l_{\mathrm{e}}}{D_{\mathrm{a}}} \exp \frac{t_{\mathrm{a}}}{D_{\mathrm{a}}}}
$$

この半経験式で $1.5 \mathrm{kV}$ で作動中の $\mu 10$ の逆流リミット值 を求めると $-156 \mathrm{~V}$ となり，実験值 $(-150 \sim-160 \mathrm{~V})$ と よく一致する．しかし，第 8 図において実験と半経験式に 


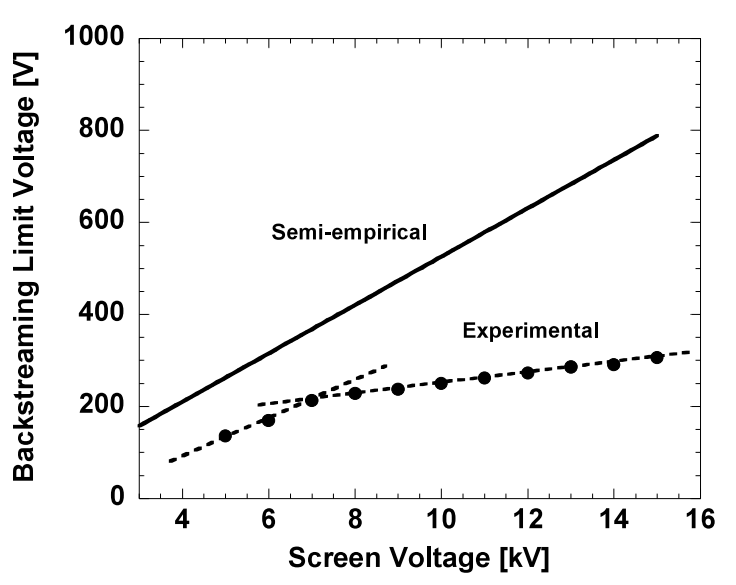

第 8 図 スクリーン電圧-逆流リミット值特性

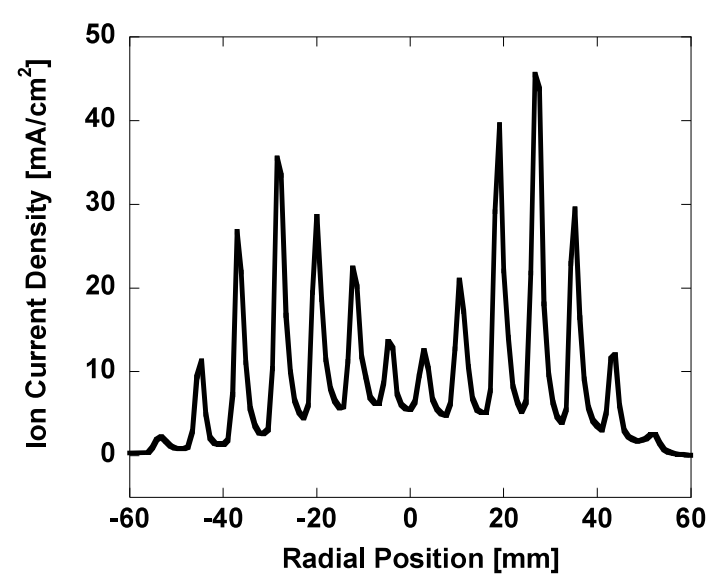

第 9 図 $\mu 10 \mathrm{HIsp}$ のピームプロファイル

よる逆流リミット值を比較すると，実験值の方がかなり低 く両者は一致していない，また，半経験式による值ではス クリーン電圧に対して逆流リミット值は直線的に増加する が, 実験值では途中で傾きが変っている.

$\mu 10 \mathrm{HIsp}$ のビームプロファイルは , 加速グリッドのイオ ンオプティクス特性を踏まえて, 加速電圧を $8 \mathrm{kV}$ として 計測を行った．乥の結果を第 9 図に示す．今回の計測はグ リッド直近で計測を行っており, グリッド孔部分でのみイ オン電流が検出されるのでビームプロファイルはピーク状 になっている．弚のイオン電流密度の分布は加速グリッド の中心付近では低くなっているが，中心から約 $35 \mathrm{~mm}$ の領 域では中心部分の 4 倍程度高くなっている.これは ECR 放電による不均一なプラズマ生成を行っているマイクロ波 放電式イオンエンジン固有の特徵を反映している．イオン 源内部のプラズマ密度が不均一であれば, グリッド孔の位 置によってイオン放出面の形状 (最適パービアンス) が異 なってくるため, このビームプロファイルデータは加速グ リッドの設計や关のイオンオプティクス特性を考察する上 で極めて重要である .

\section{6. 検 討 考 察}

高比推力マイクロ放電式イオンエンジン $\mu 10 \mathrm{HIsp}$ のイオ ン加速試験を実施し, 加速電圧 $15 \mathrm{kV}$ でのイオン加速を達
成した .これまで開発されてきたイオンエンジンでもこれ だけ高い加速電圧を使用する例は極めて少なく，国内のイ オンエンジンでは最高の加速電圧である .この加速電圧を 達成するのに不可欠な加速グリッド間の絶縁，高耐圧 DC ブロック , ガスアイソレータの各種の高電圧絶縁技術を確 立できたことは重要な成果である．今後，宇宙機搭載に向 けて小型軽量化を图ると共に耐久試験を通じて，弚の耐久 性を確認することが課題となるであろう．

本試験では加速電圧 $15 \mathrm{kV}$ に対して約 $150 \mathrm{~mA}$ のスク リーン電流を得た . 設計值 $(140 \mathrm{~mA})$ とほぼ同等の電流值 を得ており，本加速グリッドの設計が適切であることが確 認できた .これは “igx”コードによる計算結果が妥当であ り，実機サイズの加速グリッドの簡易設計にも有効である ことを示している．弚の一方で, 約 $20 \mathrm{~mA}$ のイオン電流が アクセルグリッドに流失するため, 目標のビーム電流であ る $140 \mathrm{~mA}$ を達成できなかった，弚のため目標とする推進 性能にはあと一歩届かなかった，しかし，目標性能に及ば なかったとは言え， $26 \mathrm{mN}$ の推力と 9,570 秒の比推力を達 成しており，木星探査ミッションなどの深宇宙探査ミッショ ンに相応しい推進性能を達成できている．また，この結果 からアクセルグリッドへの加速イオンの流失に対する対策 を講じることによって, 目標の推進性能が達成される見通 しを得ることもできた .

次に $\mu 10$ HIsp のイオンオプティクス特性について产の ビームプロファイルを踏まえて考察する. 本研究で取得さ れた最適なパービアンス領域は "igx”コードによる計算結果 とほぼ一致していたが , Cross-over limit , Perveance limit が共に一致せず，実験データでは最適パービアンス領域の 幅が狭くなっている.これは第 9 図に示したようにイオン 源でのプラズマ生成は不均一であるため, グリッド孔の位 置によって最適なパービアンスが異なっていることに起因 する．弚のため，加速グリッドの中心や最端部分のような プラズマか想定より薄いと思われる領域ではイオン軌道が Cross-over となり，アクセルグリッドに直撃していると推 測される.これは推進性能のみならず，イオンエンジンの 寿命を左右する加速グリッドの耐久性にも影響を与える深 刻な問題である. 従って, 今回取得されたビームプロファ イルを織り込んだ加速グリッドの設計が求められる . 具体 的にはグリッドの位置によって孔の直径を変える，隣接す るビームレット同士の静電的な干渉を小さくするためスク リーングリッドを厚くするなどの方法が考えられ，現在検 討を進めている。“igx" コードによる計算では, 計算コス 卜を抑えるために 1 孔レベルではあるが抽出可能なビーム レット電流範囲を示すことで, プラズマの不均一性に対応 している.本研究では, “igx”コードを加速グリッドの初 期設計の支援に利用しており，この目的においては十分な 計算ツールである。しかしながら，さらに進んだ詳細設計 や解析に際しては, 単孔ビームレットの軌道解析ではなく, 生成プラズマの不均一性に対応できる多孔解析が要求され る. 現在, 多くの研究機関で三次元多孔解析コードの研究 開発が進められているが, 極めて計算コストが澎大になる 
ため, 現在の計算機能力では数孔レベルの解析が限度であ り, 数百〜数千個あるグリッド孔すべてを解析できる多孔解 析ツールは実現していない.現在 , JAXA でもイオンエン ジン用加速グリッド解析ツール JIEDI (JAXA Ion Engine Development Initiatives) の開発が進められているが , 計 算コストの問題から多孔解析が実現されても数個のグリッ ド孔の解析に限定される見通しである .

続いて $\mu 10 \mathrm{HIsp}$ の電子逆流特性について考察する . (5) 式が示すようにスクリーン電圧か増大すると逆流リミット 值は増大する . 本実験でも同樣の結果が得られ, 加速電圧が $15 \mathrm{kV}$ での逆流リミット值は約 $-260 \mathrm{~V}$ であった .しかし 実際には $-300 \mathrm{~V}$ 程度でも軽微な電子逆流が見られるので， アクセルグリッドには若干のマージンを持たせて -400〜 $-500 \mathrm{~V}$ の電圧が必要であると思われる . 今後 , イオンオ プティクスが最適化されイオン軌道を十分に収束できるよ うになった段階で，アクセルグリッドの孔径をできるだけ 小さくすることも，電子逆流の抑制に極めて有効であろう.

さて, 実験と半経験式による逆流リミット值を比較する と，実験值の方が低く，さらにスクリーン電圧が $7 \mathrm{kV}$ 前 後で増加の傾きが変った .一方, 第 7 図に示したようにス クリーン電圧が高くなると, 電子逆流特性の膝部分が徐々 に緩やかになった . 本イオンエンジンではビーム電流が比 較的低いため, 中和に要する電子も少ない，従って，スク リーン電圧が高くなっても逆流してくる電子量が不足する ため逆流リミット值は半経験式による值には達せず, 最終 的には飽和傾向に転ずるので上記のような現象が生じると 推測される．また，実験による逆流リミット值が低くなる 原因としては, 本実験による求め方では本来の值よりも低 くなってしまうことも一因と思われる .この結果はビーム 電流が比較的小さいイオンエンジンを高比推力化する場合 は, 逆流リミット値を低く抑えられることを意味しており， 優れた耐久性を志向する $\mu 10 \mathrm{HIsp}$ にとっては非常に有利な 結果である．

本研究によって, 目的としていた高比推力加速グリッド と各種絶縁機器に関する基礎技術が確立できたと共に，光 の改善に向けての技術的課題や指針を明確にすることがで きた . 最も重要な技術的課題は加速グリッドのイオンオプ ティクス設計の改善であるが, 弚の他にも加速グリッドの 機械的特性の評価や長時間運転における耐久性の評価も重 要な課題である . $\mu 10 \mathrm{HIsp}$ 用加速グリッドの耐久性に関し ては, 抽出イオンのアクセルグリッドへの直撃さえ回避で きれば $\mu 10$ とほぼ同等の運転状況となるため，これと同等 の耐久性が実現できると思われる .

\section{参 考 文 献}

1) 國中 均, 堀内泰男, 西山和孝, 船木一幸, 清水幸夫, 山田哲哉: 「はやぶシさ」搭載マイクロ波放電型イオンエンジン, 日本航空宇 宙学会誌, 53 (2005), pp. 203-210.

2) Funaki, I., Satori, S. and Kuninaka, H.: Low-Power Microwave Electron Source for Ion Engine Neutralizer, Jpn. J. Appl. Phys., 37 (1998), pp. 4228-4229, Part 1.

3) Funaki, I., Kuninaka, H., Toki, K., Shimizu, Y.,
Nishiyama, K. and Horiuchi, Y.: Verification Tests of Carbon-Carbon Composite Grids for Microwave Discharge Ion Thruster, J. Propul. Power, 18 (2002), pp. 169-175.

4) 國中 均, 川口淳一郎：マイクロ波放電型イオンエンジンの宇 宙運用報告，宇宙輸送シンポジウム (平成 17 年度)，2006, pp. 331-332.

5) Brophy, J. R.: Deep Space 1 Ion Engine (Plenary), Rev. Sci. Instrum., 73 (2002), pp. 1071-1078.

6) Oleson, S. R.: Electric Propulsion Technology Development for the Jupiter Icy Moon Orbiter, Space 2004 Conference and Exhibit, 2004, pp. 1-16.

7) 川口淳一郎, ソーラーセイル WG/工学委員会 : ソーラー電力セ イルによる外惑星探査実証ミッションについて, 第 5 回宇宙科学 シンポジウム , 2005, pp. 101-124.

8) Patterson, M. J., Domonkos, M. T., Forster, J. E., Haag, T. W., Mantenieks, M. A., Pinero, L. R., Rawlin, V. K., Soulas, G. C. and Sovey, J. S.: Ion Propulsion Development Activities at the NASA Glenn Research Center, Proceedings of the 27th International Electric Propulsion Conference, IEPC Paper 01-088, 2001.

9) Patterson, M. J. : NEXT Study of Thruster Extended Performance (NEXT STEP), Proceedings of the 42nd AIAA/ASME/SAE/ASEE Joint Propulsion Conference \& Exhibit, AIAA Paper 2006-4664, 2006.

10) Forster, J. E., Haag, T., Patterson, M., Williams, G. J., Jr., Sovey, J. S., Carpenter, C., Kamhawi, H., Malone, S. and Elliot, F.: The High Power Electric Propulsion (HiPEP) Ion Thruster, NASA/TM-2004-213194, AIAA Paper 2004-381, 2004.

11) Rawlin, V. K., Williams, G. J., Pinero, L. R. and Roman, R. F.: Status of Ion Engine Development for High Power, High Specific Impulse Missions, Proceedings of the 27th International Electric Propulsion Conference, IEPC Paper 01-096, 2001.

12) 栗木恭一, 荒川義博編 : 電気推進ロケット入門, 東京大学出版会, 東京, 2003, p. 99 .

13) Forster, J. E., Kamhawi, H., Haag, T., Carpenter, C. and Williams, G.: High Power ECR Ion Thruster Discharge Characteristics, Proceedings of the 29th International Electric Propulsion Conference, IEPC Paper 2005-272, 2005.

14) Nakayama, Y., Hayashi, H., Cho, M., Funaki, I. and Kuninaka, H.: Feasibility Study on High Specific Impulse Ion Thruster with C/C Grid System, Proceedings of the 29th International Electric Propulsion Conference, IEPC Paper 2005-233, 2005

15) Nakayama, Y. and Wilbur, P. J.: Numerical Simulation of High Specific Impulse Ion Thruster Optics, Proceedings of the 27th International Electric Propulsion Conference, IEPC Paper 01-99, 2001.

16) 中山宜典 : 高比推カイオン推進機グリッドシステムの計算解析 , 宇宙技術，2 (2003), pp. 1-7.

17）林寛, 趙 孟佑,國中 均: 高比推力マイクロ波放電式イオ ンエンジン $\ulcorner\mu 10 \mathrm{HIsp} 」$ の研究状況一イオン加速試験と高電圧絶 縁機器の試作改良一，第 49 回宇宙科学技術連合講演会講演集， 2005, pp. 863-867.

18）林寛, 趙 孟佑, 國中 均: 高比推力マイクロ波放電式イオ ンエンジンの推進性能の評価, 宇宙輸送シンポジウム (平成 17 年度)，2006, pp. 333-336.

19）船木一幸, 國中 均, 都木恭一郎, 清水幸夫, 佐鳥 新: マイク 口波放電式イオンエンジン用耐久試験装置の開発，日本航空宇宙 学会論文集, 47 (1999), pp. 411-418.

20) Wilbur, P. J., Miller. J., Farnell, C. and Rawlin, V. K.: A Study of High Impulse Ion Thruster Optics, Proceedings of the 27th International Electric Propulsion Conference, IEPC Paper 01-098, 2001.

21) Kaufman, H. R.: Technology of Electron Bombardment Ion Thruster, Advances in Electronics and Electron Physics, 36 (1974), pp. 265-372. 